\title{
Assessment of Undiscovered Oil and Gas Resources of the Reggane Basin Province, Algeria, 2018
}

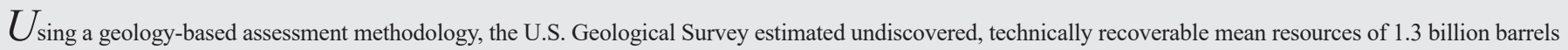
of oil and 63 trillion cubic feet of gas in the Reggane Basin Province of Algeria.

\section{Introduction}

The U.S. Geological Survey (USGS) quantitatively assessed the potential for undiscovered, technically recoverable continuous (unconventional) and conventional oil and gas resources in the Reggane Basin Province of Algeria (fig. 1). The Reggane Basin is one of a series of North African basins that achieved much of their current structural configuration through late Carboniferous-Permian (Hercynian orogen) compressional deformation (Boote and others, 1998; Coward and Ries, 2003; Badalini and others, 2009). The basin is asymmetric with a steeply dipping, structurally complex northeastern margin associated with a sedimentary section that gradually thins and shallows to the southwest. Silurian and Devonian organic-rich shales are the major petroleum source rocks in the basin (Boote and others, 1998). Organic matter in both source rocks may have reached the thermal generation window for oil during Carboniferous burial; both source rock intervals reached the gas-generation window during the Late Triassic-Jurassic (Boote and others, 1998; Logan and Duddy, 1998; Makhous and Galushkin, 2003; Zuehlke and others, 2010; Jaeger and others, 2017). Only the southwestern margin of the basin remains in the oil-generation window (Arab and Djezzar, 2011). This assessment includes an evaluation of undiscovered continuous (shale oil, shale gas, tight gas) resources and conventional oil and gas resources.

\section{Total Petroleum Systems and Assessment Units}

The USGS defined a Reggane Silurian Total Petroleum System (TPS) with the Reggane Ordovician Tight Gas Assessment Unit (AU), Reggane Silurian Shale Gas AU, and Reggane Silurian Shale Oil AU; the Reggane Devonian TPS with the Reggane Devonian Shale Gas AU and Reggane Devonian Shale Oil AU; and the Silurian-Devonian Composite TPS with the Reggane Conventional Oil and Gas AU. Silurian shales contain 3-5 weight percent residual total organic carbon, initial hydrogen index values are as much as 530 milligrams of hydrocarbon per gram of total organic carbon, and shale thickness is as much as 100 meters (Arab and Djezzar, 2011; Kaced and Arab, 2012). Devonian shales contain as much as 3 weight percent residual total organic carbon, and shale thickness is as much as 80 meters (Kaced and Arab, 2012)

The geologic model for the Silurian TPS is for oil to have been generated from organic-rich shales as early as the Carboniferous (Logan and Duddy, 1998), and some of this oil was partially retained within the shales in the southwestern part of the basin. In much of the basin, oil within the shales cracked to gas possibly during the Late Triassic-Jurassic. Gas may have migrated locally to accumulate within subjacent, low-permeability Ordovician sandstones, forming potential tight-gas accumulations. The geologic model for the Devonian TPS is similar in that oil as well as gas from thermal cracking of oil was partially retained within Devonian shales. The geologic model for the Silurian-Devonian Composite TPS is for oil and gas from both source rocks to have migrated into conventional stratigraphic traps within the basin and into structural traps mainly occurring along the faulted northeastern margin of the basin.

Assessment input data are summarized in table 1. For continuous oil and gas accumulations, input data for drainage areas, success ratios, and estimated ultimate recoveries are taken from geologic analogs in the United States.

\section{Undiscovered Resources Summary}

The USGS quantitatively assessed undiscovered oil and gas resources in six assessment units (table 2). For undiscovered, technically recoverable oil and gas resources, the mean totals are 1,296 million barrels of oil (MMBO), or 1.3 billion barrels of oil, with an F95-F5 fractile range from 20 to 3,618 MMBO; 63,199 billion cubic feet of gas (BCFG), or 63 trillion cubic feet of gas, with an F95-F5 fractile range from 13,259 to 147,989 BCFG; and 266 million barrels of natural gas liquids (MMBNGL) with an F95-F5 fractile range from 44 to 692 MMBNGL. Of the mean total of 1,296 MMBO, 93 percent, or 1,211 MMBO, is continuous oil, and of the mean of 63,198 BCFG, 96 percent, or 60,779 BCFG, is continuous gas.

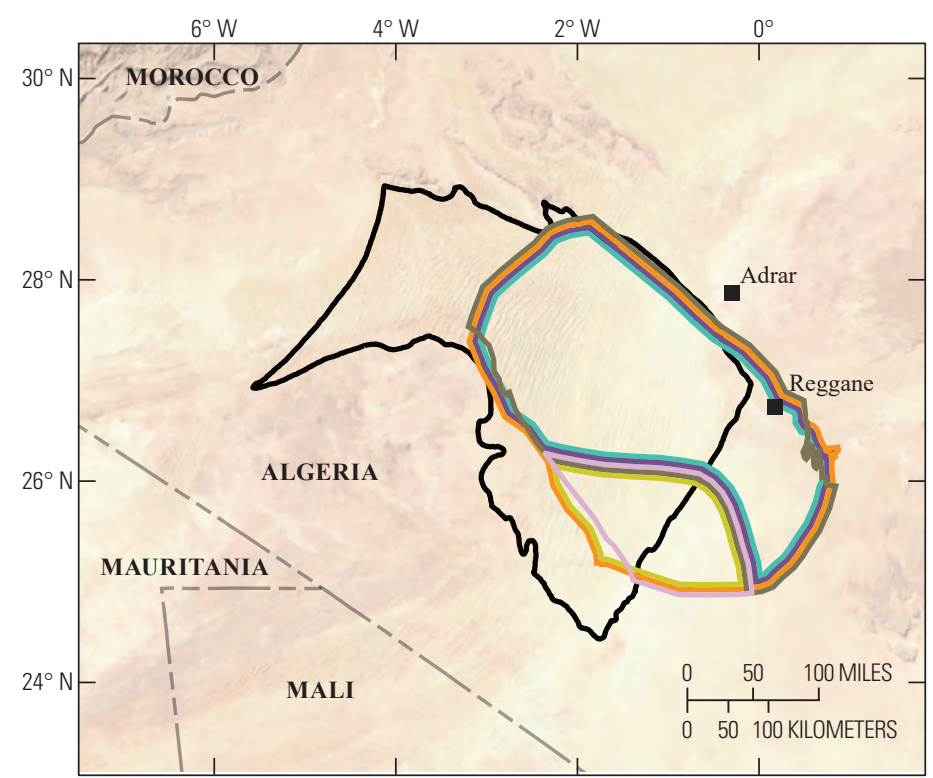

Base map from U.S. Department of the Interior National Park Service EXPLANATION
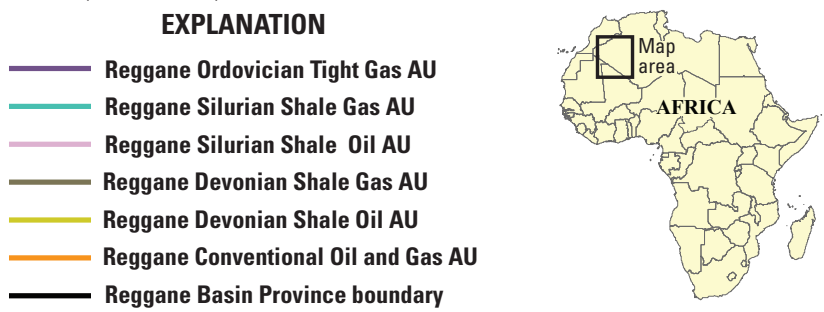

Figure 1. Map showing the six assessment units (AUs) in the Reggane Basin Province, Algeria.

\section{References Cited}

Arab, M., and Djezzar, S., 2011, Gas potential evaluation of Reggane Basin, southwestern Algeria [abs.], in Offshore Mediterranean Conference, Ravenna, Italy, March 23-25, 2011, Proceedings: Offshore Mediterranean Conference, Paper OMC-2011-046, accessed November 2, 2018 at https://www.researchgate.net/publication/293653456 Gas Potential Evaluation Reggane Basin Southwestern Algeria OMC Conference.

Badalini, G., Redfern, J., and Carr, I.D., 2009, A synthesis of current understanding of the structural evolution of North Africa: Journal of Petroleum Geology, v. 25, no. 3, p. 249-258.

Boote, D.R.D., Clark-Lowes, D.D., and Traut, M.W., 1998, Palaeozoic petroleum systems of North Africa, in MacGregor, D.S., Moody, R.T.J., and Clark-Lowes, D.D., eds., Petroleum geology of North Africa: The Geological Society of London, Special Publication No. 132, p. 7-68.

Coward, M.P., and Ries, A.C., 2003, Tectonic development of North African basins, in Arthur, T.J., MacGregor, D.S., and Cameron, N.R., eds., Petroleum geology of AfricaNew themes and developing technologies: The Geological Society of London, Special Publication No. 207, p. 61-83.

Jaeger, H., Bechstaedt, T., and Mohr, M., 2017, Multi-phase thermal history of Palaeozoic basins in NW-Africa (Algeria, Morocco) and its impact on hydrocarbon system development [abs.]: American Association of Petroleum Geologists, Search and Discovery Article No. 90313, accessed November 2, 2018, at http://www.searchanddiscovery.com/ abstracts/pdf/2018/90313ar/abstracts/ndx_jaeger.pdf?q=\%2BauthorStrip\%3Ajaeger. 
Table 1. Key input data for five continuous assessment units (AUs) and one conventional AU in the Reggane Basin Province, Algeria.

[\%, percent; EUR, estimated ultimate recovery per well; BCFG, billion cubic feet of gas; MMBO, million barrels of oil. Well drainage area, success ratio, and EUR are defined partly using U.S. shale-oil and shale-gas analogs. The average EUR input is the minimum, median, maximum, and calculated mean. Shading indicates not applicable]

\begin{tabular}{|c|c|c|c|c|c|c|c|c|}
\hline \multirow{2}{*}{$\begin{array}{l}\text { Assessment input data- } \\
\text { Continuous AUs }\end{array}$} & \multicolumn{4}{|c|}{ Reggane Ordovician Tight Gas AU } & \multicolumn{4}{|c|}{ Reggane Silurian Shale Gas AU } \\
\hline & Minimum & Mode & Maximum & $\begin{array}{l}\text { Calculated } \\
\text { mean }\end{array}$ & Minimum & Mode & Maximum & $\begin{array}{l}\text { Calculated } \\
\text { mean }\end{array}$ \\
\hline Potential production area of AU (acres) & 1,000 & $9,418,000$ & $18,835,000$ & $9,418,000$ & 1,000 & $9,418,000$ & $18,835,000$ & $9,418,000$ \\
\hline Average drainage area of wells (acres) & 40 & 80 & 120 & 80 & 80 & 120 & 160 & 120 \\
\hline Area untested in $\mathrm{AU}(\%)$ & 100 & 100 & 100 & 100 & 100 & 100 & 100 & 100 \\
\hline Success ratio (\%) & 10 & 50 & 90 & 50 & 10 & 50 & 90 & 50 \\
\hline Average EUR (BCFG) & 0.08 & 0.4 & 1.2 & 0.440 & 0.1 & 0.4 & 1.3 & 0.447 \\
\hline AU probability & 1.0 & & & & 1.0 & & & \\
\hline \multirow{2}{*}{$\begin{array}{l}\text { Assessment input data- } \\
\text { Continuous AUs }\end{array}$} & \multicolumn{4}{|c|}{ Reggane Silurian Shale Oil AU } & \multicolumn{4}{|c|}{ Reggane Devonian Shale Gas AU } \\
\hline & Minimum & Mode & Maximum & $\begin{array}{l}\text { Calculated } \\
\text { mean }\end{array}$ & Minimum & Mode & Maximum & $\begin{array}{l}\text { Calculated } \\
\text { mean }\end{array}$ \\
\hline Potential production area of AU (acres) & 1,000 & $2,767,000$ & $5,533,000$ & $2,767,000$ & 1,000 & $9,086,000$ & $18,172,000$ & $9,086,333$ \\
\hline Average drainage area of wells (acres) & 60 & 100 & 120 & 93.3 & 80 & 120 & 160 & 120 \\
\hline Area untested in $\mathrm{AU}(\%)$ & 100 & 100 & 100 & 100 & 100 & 100 & 100 & 100 \\
\hline Success ratio $(\%)$ & 10 & 50 & 90 & 50 & 10 & 50 & 90 & 50 \\
\hline Average EUR (MMBO, oil; BCFG, gas) & 0.01 & 0.04 & 0.2 & 0.049 & 0.1 & 0.4 & 1.3 & 0.447 \\
\hline AU probability & 0.9 & & & & 1.0 & & & \\
\hline \multirow{2}{*}{$\begin{array}{l}\text { Assessment input data- } \\
\text { Continuous AU }\end{array}$} & \multicolumn{4}{|c|}{ Reggane Devonian Shale Oil AU } & \multirow{9}{*}{\multicolumn{4}{|c|}{$\begin{array}{l}\text { Reggane Basin Province } \\
\text { Assessment Team } \\
\quad \text { Christopher J. Schenk, Michael E. Brownfield, } \\
\text { Tracey J. Mercier, Cheryl A. Woodall, Phuong A. Le, } \\
\text { Marilyn E. Tennyson, Thomas M. Finn, Kristen R. Marra, } \\
\text { Stephanie B. Gaswirth, Heidi M. Leathers-Miller, } \\
\text { Janet K. Pitman, and Ronald M. Drake II }\end{array}$}} \\
\hline & Minimum & Mode & Maximum & $\begin{array}{c}\text { Calculated } \\
\text { mean }\end{array}$ & & & & \\
\hline Potential production area of AU (acres) & 1,000 & $2,476,000$ & $4,951,000$ & $2,476,000$ & & & & \\
\hline Average drainage area of wells (acres) & 60 & 100 & 120 & 93.3 & & & & \\
\hline Area untested in $\mathrm{AU}(\%)$ & 100 & 100 & 100 & 100 & & & & \\
\hline Success ratio (\%) & 10 & 50 & 90 & 50 & & & & \\
\hline Average EUR (MMBO) & 0.01 & 0.04 & 0.2 & 0.049 & & & & \\
\hline AU probability & 0.9 & & & & & & & \\
\hline \multirow{2}{*}{$\begin{array}{l}\text { Assessment input data- } \\
\text { Conventional AU }\end{array}$} & \multicolumn{4}{|c|}{ Reggane Conventional Oil and Gas AU } & & & & \\
\hline & Minimum & Median & Maximum & $\begin{array}{l}\text { Calculated } \\
\text { mean }\end{array}$ & \multirow{5}{*}{\multicolumn{4}{|c|}{$\begin{array}{l}\text { For More Information } \\
\text { Assessment results are also available at the } \\
\text { USGS Energy Resources Program website at } \\
\text { https://energy.usgs.gov. }\end{array}$}} \\
\hline Number of oil fields & 1 & 4 & 16 & 4.42 & & & & \\
\hline Number of gas fields & 1 & 20 & 80 & 22.06 & & & & \\
\hline Size of oil fields (MMBO) & 5 & 10 & 500 & 19.29 & & & & \\
\hline Size of gas fields (BCFG) & 30 & 60 & 2,000 & 102.02 & & & & \\
\hline AU probability & 1.0 & & & & & & & \\
\hline
\end{tabular}

Table 2. Results for five continuous assessment units (AUs) and one conventional AU in the Reggane Basin Province, Algeria.

[MMBO, million barrels of oil; BCFG, billion cubic feet of gas; NGL, natural gas liquids; MMBNGL, million barrels of natural gas liquids. Results shown are fully risked estimates. F95 represents a 95-percent chance of at least the amount tabulated; other fractiles are defined similarly. Fractiles are additive under the assumption of perfect positive correlation. Shading indicates not applicable]

\begin{tabular}{|c|c|c|c|c|c|c|c|c|c|c|c|c|c|c|}
\hline \multirow{3}{*}{$\begin{array}{l}\text { Total petroleum systems } \\
\text { and assessment units (AUs) }\end{array}$} & \multirow{3}{*}{$\underset{\text { probability }}{\mathrm{AU}}$} & \multirow{3}{*}{$\begin{array}{l}\text { Accumulation } \\
\text { type }\end{array}$} & \multicolumn{12}{|c|}{ Total undiscovered resources } \\
\hline & & & \multicolumn{4}{|c|}{ Oil (MMBO) } & \multicolumn{4}{|c|}{ Gas (BCFG) } & \multicolumn{4}{|c|}{ NGL (MMBNGL) } \\
\hline & & & F95 & F50 & F5 & Mean & F95 & F50 & F5 & Mean & F95 & F50 & F5 & Mean \\
\hline \multicolumn{15}{|c|}{ Reggane Silurian Total Petroleum System } \\
\hline Reggane Ordovician Tight Gas AU & 1.0 & Gas & & & & & 5,407 & 21,985 & 60,150 & 25,927 & 17 & 81 & 268 & 104 \\
\hline Reggane Silurian Shale Gas AU & 1.0 & Gas & & & & & 3,569 & 14,462 & 41,044 & 17,359 & 12 & 53 & 180 & 69 \\
\hline Reggane Silurian Shale Oil AU & 0.9 & Oil & 0 & 494 & 1,789 & 641 & 0 & 288 & 1,100 & 385 & 0 & 5 & 18 & 6 \\
\hline \multicolumn{15}{|c|}{ Reggane Devonian Total Petroleum System } \\
\hline Reggane Devonian Shale Gas AU & 1.0 & Gas & & & & & 3,447 & 14,038 & 39,694 & 16,766 & 11 & 52 & 176 & 67 \\
\hline Reggane Devonian Shale Oil AU & 0.9 & Oil & 0 & 438 & 1,604 & 570 & 0 & 256 & 988 & 342 & 0 & 4 & 16 & 5 \\
\hline Total undiscovered continuous resources & & & 0 & 932 & 3,393 & 1,211 & 12,423 & 51,029 & 142,976 & 60,779 & 40 & 195 & 658 & 251 \\
\hline \multicolumn{15}{|c|}{ Silurian-Devonian Composite Total Petroleum System } \\
\hline \multirow{2}{*}{ Reggane Conventional Oil and Gas AU } & \multirow{2}{*}{1.0} & Oil & 20 & 63 & 225 & 85 & 38 & 123 & 462 & 170 & 0 & 1 & 5 & 2 \\
\hline & & Gas & & & & & 798 & 2,000 & 4,551 & 2,250 & 4 & 12 & 29 & 13 \\
\hline Total undiscovered conventional resources & & & 20 & 63 & 225 & 85 & 836 & 2,123 & 5,013 & 2,420 & 4 & 13 & 34 & 15 \\
\hline Total undiscovered resources & & & 20 & 995 & 3,618 & 1,296 & 13,259 & 53,152 & 147,989 & 63,199 & 44 & 208 & 692 & 266 \\
\hline
\end{tabular}

Kaced, M., and Arab, M., 2012, The potential of shale gas plays in Algeria, in 25th World Gas Conference, Kuala Lumpur, Malaysia, June 4-8, 2012, Proceedings: International Gas Union, 18 p., accessed November 2, 2018, at https://www.researchgate.net/publication/282730474_ Shale gas potential_of Algerian_Basins.

Logan, P., and Duddy, I., 1998, An investigation of the thermal history of the Ahnet and Reggane Basins, central Algeria, and the consequences for hydrocarbon generation and accumulation, in MacGregor, D.S., Moody, R.T.J., and Clark-Lowes, D.D., eds., Petroleum geology of North Africa: The Geological Society of London, Special Publication No. 132, p. 131-155.
Makhous, M., and Galushkin, Y.I., 2003, Burial history and thermal evolution of the southern and western Saharan basins-Synthesis and comparison with the eastern and northern Saharan basins: American Association of Petroleum Geologists Bulletin, v. 87, no. 11 , p. $1799-1822$.

Zuehlke, R., Lewandowski, E., Jäger, H., Bechstädt, T., Aicha, R., Wirth, B., and Böckmann, M., 2010, Integrated basin and HC systems model, Silurian-Carboniferous, southern Algeria: American Association of Petroleum Geologists, Search and Discovery Article No. 50344, 25 p., accessed October 30, 2018, at http://www.searchanddiscovery.com/pdfz/ documents/2010/50344zuehlke/ndx_zuehlke.pdf.html?q=\%252BauthorStrip\%253Azuehlke. 